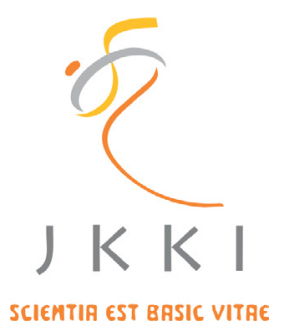

Jurnal Kedokteran dan Kesehatan Indonesia

Indonesian Journal of Medicine and Health

Journal homepage : www.journal.uii.ac.id/index.php/JKKI

\title{
Successful late repair of popliteal artery rupture with compartment syndrome
}

\author{
Supomo*1 \\ ${ }^{1}$ Thoracic and Cardiovascular Surgery Division, Department of Surgery, Dr. Sardjito General Hospital, Gajah Mada \\ University, Yogyakarta Indonesia
}

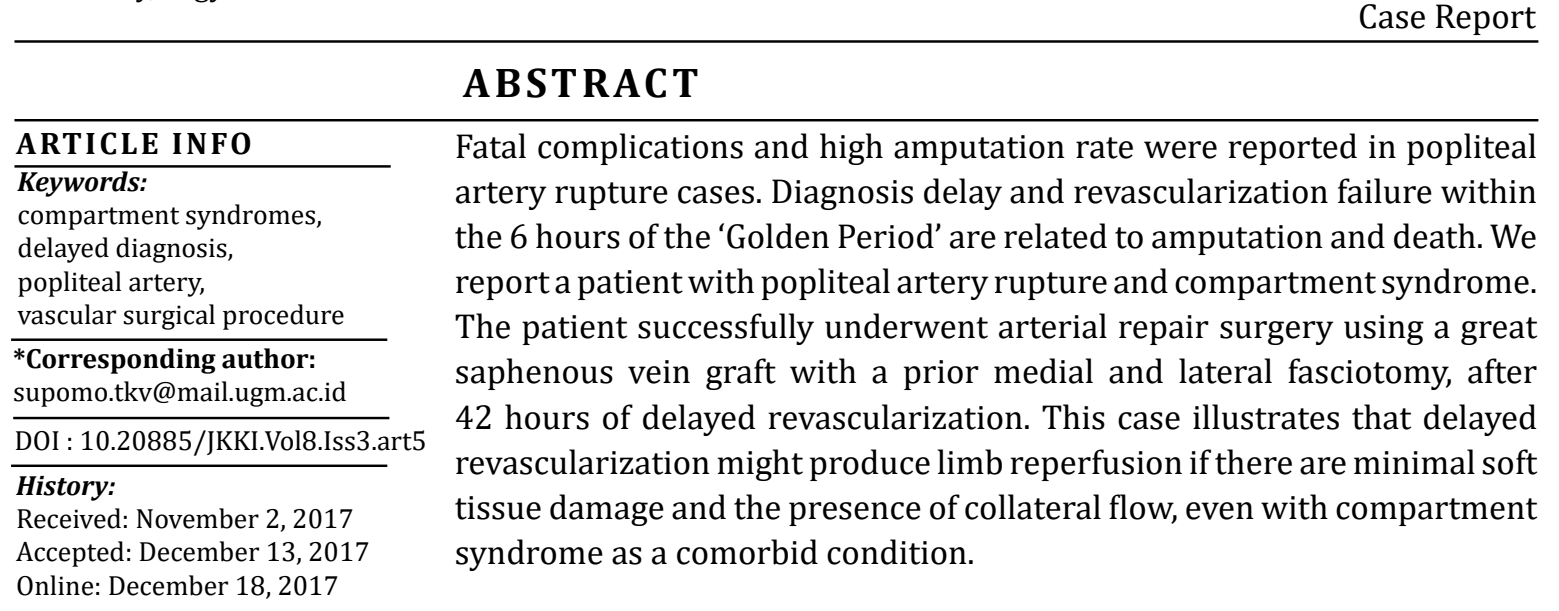

Komplikasi yang fatal dan tingkat amputasi yang tinggi telah dilaporkan pada kasus ruptur arteri popliteal. Keterlambatan diagnosis dan kegagalan revaskularisasi dalam 6 jam "Periode Emas" berhubungan dengan amputasi dan kematian, bahkan ketika tersedia intervensi spesialistik. Kami melaporkan pasien dengan ruptur arteri popliteal dan sindroma kompartemen. Pasien ini sukses menjalani operasi perbaikan arteri menggunakan graft vena saphena magna dengan sebelumnya menjalani fasciotomi medial dan lateral, setelah 42 jam keterlambatan revaskularisasi. Kasus ini mengilustrasikan bahwa keterlambatan revaskularisasi dapat memberikan reperfusi ekstremitas jika terdapat kerusakan jaringan lunak minimal dan keberadaan aliran kolateral, bahkan dengan adanya sindroma kompartemen. yang berikatan secara kovalen dengan bagian luar peptidoglikan, yang penting dalam pembelahan sel dan proteksi osmotik bakteri. Dengan demikian, diduga bahwa mekanisme kerja xanthone melibatkan kerusakan dinding sel dan membran sel bakteri.

\section{INTRODUCTION}

Popliteal artery rupture is uncommon accounting for only $0.2 \%$ of all traumas. This rare injury is often fraught with destructive soft tissue defects, bone disruption, and nerve deficits, leading to poor outcome and reported amputation rate as high as $65 \% .{ }^{1}$ Diagnosis delay and revascularization failure within the 6 hours of the 'Golden Period' are related to $78 \%$ of amputation and death, even when specialist intervention is available. ${ }^{2}$ In addition, the presence of extremity compartment syndrome in vascular injury is associated with significant morbidity and mortality. ${ }^{3}$ Our case was unique since the patient had delayed revascularization for 42 hours with compartment syndrome as a comorbid condition yet successfully underwent arterial repair surgery without serious complication. 


\section{CASE REPORT}

A 29-year-old male was presented to our emergency department after a motorcycle accident. Physical examination showed lacerations at his left knee and at the distal part of his left popliteal fossa (Figure 1). Debridement of the lacerations was performed. Twenty-four hours after debridement, the patient complained of pain in his left foot. The distal part of his left foot was swollen and cold, with weak pulses of the dorsalis pedis artery (Figure 2). The peripheral oxygen saturation of the distal part of his left foot was $55-60 \%$. We diagnosed the patient with compartment syndrome and decided to perform the fasciotomy (Figure 2). Twelve hours after medial and lateral fasciotomy, his left foot remained cold and the peripheral oxygen saturation also remained low. The pulse of the dorsalis pedis artery was absent. We diagnosed the patient with popliteal artery rupture. Fortytwo hours after the trauma, popliteal artery repair was performed using a great saphenous vein graft from the patient (Figure 3 ). There were no serious complications during and after the surgery. The perfusion of the distal part of his left foot was returned and the only sequel found was minimal ankle stiffness.

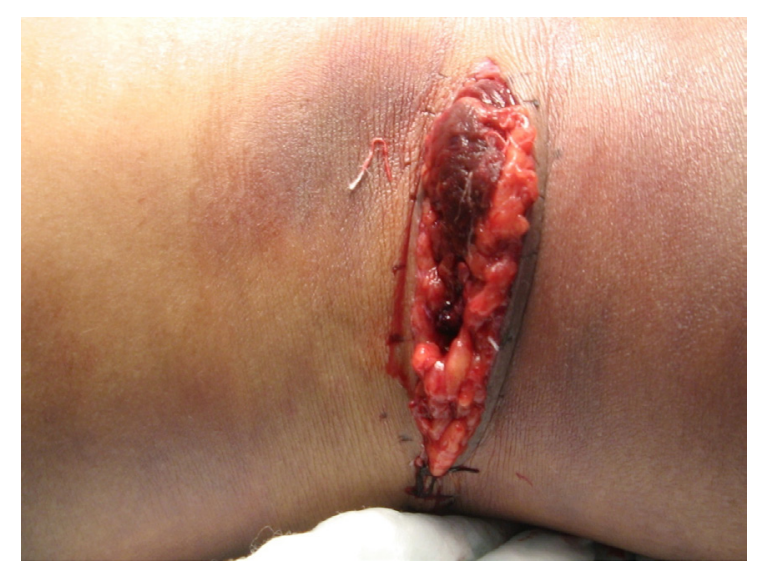

Figure 1. Laceration at the distal part of left popliteal fossa.
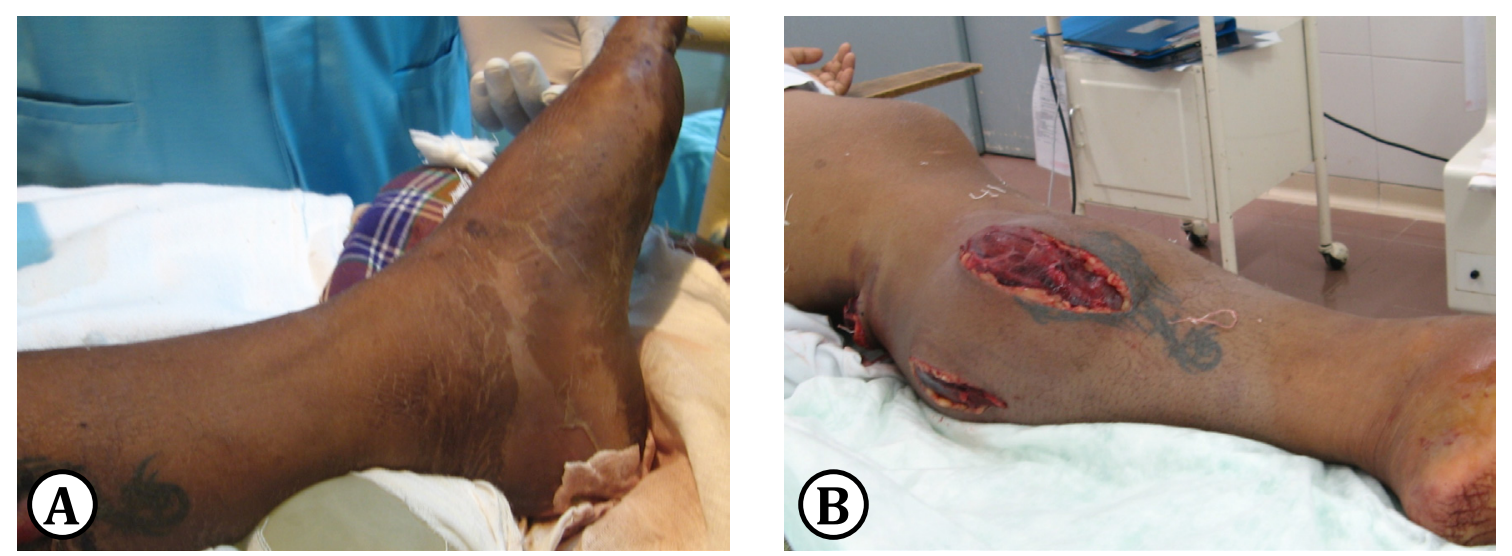

Figure 2. (A) Swollen left foot before fasciotomy and (B) left foot medial and lateral fasciotomy. 

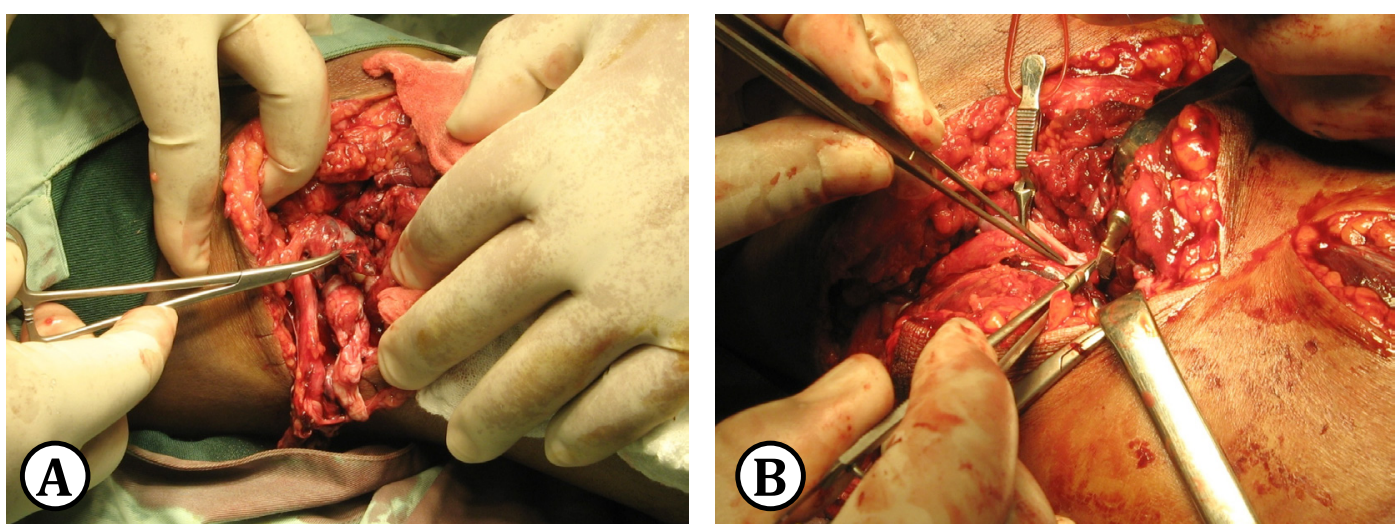

Figure 3. (A) Ruptured popliteal artery before repair (circle) and (B) great saphenous vein graft (arrow)

\section{DISCUSSION}

Popliteal artery ruptures are uncommon and associated with poor outcome. ${ }^{1}$ Early diagnosis and immediate intervention are mandatory to save the extremities and lives of the patients. Failure to vascularize within 6 hours results in an unacceptably high amputation rate and death. ${ }^{2}$ During the first 6 hours, extremity salvage rate is $90 \%$. It is dramatically decreased to $50 \%$ during 12 to 18 hours of ischemia and $20 \%$ for ischemia in excess of 24 hours. ${ }^{4}$

Artery ruptures involve conditions that can lead to compartment syndrome. Some cases reported that compartment syndrome happened after arterial rupture. ${ }^{5}$ Compartment syndrome, a clinical condition resulting from pathologically increased tissue pressure in a nonexpansive tissue space, may occur in the setting of lower extremity trauma and is associated with significant morbidity and mortality. Furthermore, fasciotomy needs to be performed to reduce the risk of limb loss and death. ${ }^{3}$

Many factors, such as the extent of soft tissue damage, the capacity of collaterals, pre-existing arterial disease, and the ischemia time may affect the clinical outcomes. ${ }^{6}$ Mckenzie et al. ${ }^{7}$ found that the greatest impact on decision making between limb salvage and amputation depend on the severity of soft tissue injury. Prolonged ischemia is a well-recognized predictor of cell death, but the tolerance period varies between persons and depends on the severity of the ischemia and the presence of collateral flow. ${ }^{8}$

In our case, the patient had delayed revascularization for 42 hours with compartment syndrome as a comorbid condition. However, he had minimal soft tissue damage without the involvement of skeletal damage (Figure 1). Post-operative detection of peripheral oxygen saturation of the distal part of his left foot after prolonged delay of revascularization indicated the presence of collateral flow. ${ }^{8}$

\section{CONCLUSION}

Early diagnosis and revascularization of vascular injury are mandatory. However, in the case of minimal soft tissue damage and the presence of collateral flow, delayed revascularization might produce limb reperfusion, even with compartment syndrome as a comorbid condition.

\section{ACKNOWLEDGMENT}

I would like to thank Handy Darmawan, M.D. and Adika Zhulhi Arjana, M.D. for their help in data collection and manuscript editing.

\section{REFERENCES}

1. Macedo FIB, Sciarretta JD, Salsamendi J, Karmacharya J, Romano A, Namias N. Repair of an acute blunt popliteal artery trauma via endovascular approach. Annals of Vascular Surgery. 2015;29(2):366.e5-10.

2. Sharma D, Goyal G, Singh A, Sisodia A, Devgarha S, Mathur RM. Management of vascu- 
lar trauma: A single center experience. Indian Journal of Vascular and Endovascular Surgery. 2014;1(1):3-7.

3. Farber A, Tan T-W, Hamburg NM, Kalish JA, Joglar F, Onigman T, et al. Early fasciotomy in patients with extremity vascular injury is associated with decreased risk of adverse limb outcomes: A review of the National Trauma Data Bank. Injury. 2013;43(9):1486-91.

4. Rowe VL, Salim A, Lipham J, Asensio JA. Shank vessel injuries. Surgical Clinics of North America. 2002;82(1):91-104.

5. Songur M, Zehir S, Oz II, Kalem M. Gluteal compartment syndrome secondary to superior gluteal artery injury following pelvis fracture: A case report and review of literature. Turkish Journal of Emergency Medicine. 2016;16:31-3.

6. Shi L. The delayed management of main arterial injuries in extremity trauma: Surgical challenges and outcomes. Pakistan Journal of Medical Sciences. 2013;29(1):64-7.

7. MacKenzie EJ, Bosse MJ, Kellam JF, Burgess AR, Webb LX, Swiontkowski MF, et al. Factors influencing the decision to amputate or reconstruct after high-energy lower extremity trauma. The Journal of Trauma. 2002;52(4):641-9.

8. Huynh TTT, Pham M, Griffin LW, Villa MA, Przybyla JA, Torres RH, et al. Management of distal femoral and popliteal arterial injuries: An update. The American Journal of Surgery. 2006;192:773-8. 